DOI: 10.35757/RPN.2009.17.03

Wanda Jarząbek

\title{
W CIENIU PROBLEMU GRANICZNEGO. POLSKA A PROCES JEDNOCZENIA NIEMIEC W LATACH 1989-1990
}

Podział Niemiec po II wojnie światowej stał się jednym z symboli zimnej wojny. Łagodzenie nastrojów zimnowojennych stwarzało również nadzieje na odzyskanie przez Niemców jedności państwowej. Od połowy lat osiemdziesiątych zaczęły się zmiany w polityce międzynarodowej, szczególnie widoczne po 1985 roku, gdy sekretarzem generalnym Komunistycznej Partii Związku Radzieckiego został Michaił Gorbaczow. Nowe kierownictwo partyjne musiało uporać się z kryzysem ekonomicznym w ZSRR i stanęło także przed koniecznością zmierzenia się z faktem nieadekwatności swojego arsenału militarnego w stosunku do tego, który był w dyspozycji USA i krajów NATO. Rozpoczęły się rozmowy rozbrojeniowe między ZSRR i USA oraz podjęto próby rozwikłania konfliktów w Indochinach, Angoli, rogu Afryki. W lutym 1989 roku zakończyło się wycofywanie wojsk ZSRR z Afganistanu.

ZSRR starał się zaktywizować swoją politykę europejską czego przejawem stała się m.in. propozycja budowy „wspólnego europejskiego domu", przedstawiona przez Gorbaczowa w 1988 roku. Coraz częściej mówiono o kwestii zjednoczenia Niemiec. W październiku 1988, Helmut Kohl w czasie wizyty w Moskwie nawiązał do najważniejszego problemu Deutschlandpolitik; gdy mówił o konieczności przezwyciężania podziału Europy - co było jednym z elementów koncepcji „wspólnego europejskiego domu” - dawał do zrozumienia, że musi dotyczyć to też Niemiec. Moskwa zaczęła zresztą w oficjalnych wypowiedziach 
sygnalizować, że zmienia swoją politykę niemiecką, choć raczej chciała uniknąć zjednoczenia.

Zamknięciem ofensywy dyplomatyczno-propagandowej Moskwy stało się wystąpienie Gorbaczowa w ONZ w grudniu 1988, które miało być odpowiedzią na słynną mowę Churchilla z Fulton w 1946 roku i mówić o konieczności zniesienia żelaznej kurtyny ${ }^{1}$. Wystąpienie to jest też czasem traktowane jako ogłoszenie wycofania się Moskwy z doktryny Breżniewa czy też kolejne potwierdzenie tego faktu. Nie ulega jednak wątpliwości, że zmieniała się polityka ZSRR wobec krajów bloku, poszerzało się ich pole manewru.

\section{Stosunki polsko-niemieckie w przededniu upadku muru berlińskiego}

Problem zjednoczenia Niemiec zajmował ważne miejsce $\mathrm{w}$ polityce zagranicznej PRL. Po powstaniu dwóch państw niemieckich w 1949 roku Warszawa była w zasadzie zainteresowana utrzymaniem rozbicia Niemiec i to nie ze względów ideologicznych (NRD była wszak państwem bloku wschodniego i zjednoczenie Niemiec mogło też doprowadzić do powstania Niemiec komunistycznych), ale ze względów geopolitycznych. Uważano, że dwa państwa niemieckie stanowią relatywnie mniejsze zagrożenie dla polskich interesów. W połowie lat sześćdziesiątych sądzono, że złagodzenie napięcia w stosunkach Wschód-Zachód służyłoby zmianie pozycji RFN w stosunkach międzynarodowych, stałaby się ona państwem odgrywającym większą rolę polityczna, co wraz z dużym i wciąż rosnącym potencjałem ekonomicznym sprawiało, że sytuacja Polski uległaby pogorszeniu. Odzyskiwanie zaś przez RFN wiarygodności w stosunkach międzynarodowych w konsekwencji ułatwiałoby także przyszłe zjednoczenie Niemiec. Taki sposób myślenia miał duży wpływ na tworzenie polskich planów dotyczących Konferencji Bezpieczeństwa i Współpracy w Europie ${ }^{2}$.

1 V. Zubok: New Evidence on the "Soviet Factor in the Peaceful Revolutions of 1989", „Cold War International History Process Bulletin” (CWIHPB) 2001, nr 12/13, s. 9.

2 Notatka w sprawie propozycji Polski dotyczacych bezpieczeństwa europejskiego, Warszawa 5 stycznia 1967 r., w: W. Jarząbek: Polska wobec Konferencji Bezpieczeństwa i Wspótpracy 
Podpisanie w grudniu 1970 roku warszawskiego Układu o podstawach normalizacji stosunków między PRL a RFN tylko częściowo rozwiało polskie obawy i nawet jeśli generalnie w latach siedemdziesiątych dominował optymizm co do możliwości współpracy między RFN a PRL obawy dotyczące celów RFN i ich wpływu na stosunki dwustronne pozostały i narastały, aby powrócić w latach osiemdziesiątych, szczególnie $\mathrm{w}$ ich drugiej połowie. Warszawa $\mathrm{z}$ niepokojem śledziła przede wszystkim stosunki na linii Moskwa-Bonn oraz Berlin Wschodni-Bonn. Zarówno ZSRR, jak i inne kraje bloku poprawiały relacje dwustronne z RFN. Niemniej nie dotyczyło to PRL.

Tak jak i inne kraje bloku, Warszawa poszukiwała możliwości uzyskania wsparcia ekonomicznego i RFN odgrywała w tych kalkulacjach niebagatelną rolę. Zdawano sobie mimo to sprawę, że w tym czasie kraje EWG prowadziły w dużym stopniu uzgodniona, wspólną politykę wobec poszczególnych krajów i na podstawie informacji, pochodzących zarówno ze źródeł dyplomatycznych, jak i wywiadowczych, wiedziano, że kraje EWG uzależniają nawiązanie współpracy od reform wewnętrznych ${ }^{3}$. Również w przypadku rozmów dwustronnych z RFN, obejmujących m.in. restrukturyzację długów PRL, problem przestrzegania praw człowieka odgrywał dużą rolę. W przeciągu 1988 roku Warszawa na próżno próbowała zmienić negatywne nastawienie RFN do udzielenia Warszawie wsparcia ekonomicznego ${ }^{4}$. Wobec częstego podnoszenia przez RFN problematyki z dziedziny trzeciego koszyka, Józef Czyrek proponował m.in. „[...] pilnie rozważyć możliwość stworzenia odpowiedniej atmosfery i wywarcia wpływu na stanowisko rządu i partii

w Europie. Plany i rzeczywistość 1964-1975, Warszawa 2008, s. 179. Szerzej na ten temat ibidem, s. 13 i n.

3 IPN BU, 0449/9, t. 8, depesza z Rzymu do MSW, 5 grudnia 1988. Chodziło przede wszystkim o postępy w dziedzinie przestrzegania praw człowieka, swobody publikacji, zgromadzeń, ułatwień $\mathrm{w}$ ruchu osobowym, wprowadzenia pluralizmu politycznego i związkowego, liberalizacji w dziedzinie religijnej i narodowościowej oraz zaangażowania na rzecz rozbrojenia - szczególnie konwencjonalnego (przed ONZ). Na razie, według głównych państw zachodnich, stosunki handlowe powinny opierać się nie tyle na preferencjach, co na znoszeniu restrykcji, głównie w ramach GATT. Dalsze kroki leżały po stronie krajów bloku, w tym władz PRL.

4 AAN, KC PZPR, Wydział Zagraniczny 202 (973/200), Rozmowa z Ministrem Stanu w Federalnym Urzędzie Kanclerskim Wolfgangiem Schäuble, (odbyta w czasie wizyty Józefa Czyrka w RFN), która miała miejsce w dniach 19-23 kwietnia 1988 roku). 
politycznych RFN poprzez zademonstrowanie dobrej woli i gotowości rozwiązywania niektórych spektakularnych w warunkach RFN spraw, $\mathrm{np}$. istotne zwiększenie zezwoleń na przesiedlenia, zgoda na podjęcie rozmów w sprawie wymiany młodzieżowej i jej umownego uregulowania $^{\prime \prime}$. W czasie wizyty ministra spraw zagranicznych RFN Hansa-Dietricha Genschera w Polsce w dniach 10-13 stycznia 1988 roku (wizyty, którą strona niemiecka odkładała od trzech lat), pojawił się jeszcze jeden ważny problem - prawa mniejszości niemieckiej w Polsce; w tej sprawie jednak Warszawa nadal nie była gotowa do podjęcia decyzji (chodziło o prawa kulturalne mniejszości, prawo do nauki języka) ${ }^{6}$.

W styczniu 1989 roku doszło do wizyty premiera Mieczysława Rakowskiego w Bonn. Ważnym jej efektem stało się powołanie pełnomocników ds. kontaktów dwustronnych. Z polskiej strony pełnomocnikiem został Ernest Kucza, w tym czasie kierownik Wydziału Zagranicznego KC, a wcześniej wieloletni pracownik MSZ zajmujący się problematyką niemiecką ze strony niemieckiej Horst Teltschik, wysoki pracownik Urzędu Kanclerskiego i doradca kanclerza Helmuta Kohla.

W czasie jednego z pobytów w Warszawie Horst Teltschik przeprowadził także rozmowę z współpracownikiem gen. Jaruzelskiego, ppłk. Wiesławem Górnickim, przede wszystkim na temat możliwości złożenia przez kanclerza Helmuta Kohla wizyty w Warszawie. W notatce sporządzonej po rozmowie Górnicki zwrócił uwagę, że jego rozmówca powiedział wprost, iż „obie strony muszą poczynić ustępstwa, aby wizyta zakończyła się sukcesem”, oraz że „istnieje ścisły związek między postępem $\mathrm{w}$ normalizacji stosunków dwustronnych a tempem przemian wewnętrznych w Polsce" ${ }^{\prime 7}$.

Ciekawym elementem rozmowy była, chyba świadoma, próba Górnickiego zastosowania pewnego szantażu, w celu nakłonienia RFN do przystania na postulaty Warszawy, jak można sądzić głównie ekonomiczne. Argumenty te zdziwiły też rozmówcę niemieckiego. Gór-

5 Ibidem, Ocena i wnioski (do Informacji nt. wizyty członka BP, sekretarza KC PZPR i Przewodniczącego Komisji Spraw Zagranicznych Sejmu, tow. Józefa Czyrka w RFN, b.d.

6 D. Bingen: Polityka Republiki Bońskiej wobec Polski. Od Adenauera do Kohla 1949-1991, Kraków 1997, s. 230.

7 AAN, KC PZPR, WZ 973/85, Notatka W. Górnickiego z 16 lutego 1989. 
nicki powiedział mianowicie, że „demokratyzacja życia politycznego w PRL aktywizuje również i tendencje endeckie, tradycyjnie związane $\mathrm{z}$ niezwykle głęboką orientacją antyniemiecką" ${ }^{8}$. Użycie tego argumentu świadczyć może o determinacji ekipy rządzącej i jej chęci utrzymania władzy, a oczywiste było także to, że poprawa sytuacji ekonomicznej kraju (możliwa do osiągnięcia, gdyby doszło do udzielenia Warszawie kredytów i restrukturyzacji długów) mogłaby być czynnikiem wzmacniającym pozycję rządzących. Zabrzmiał on szczególnie interesująco wobec faktu wieloletniego instrumentalizowania kwestii niemieckiej przez PZPR i wobec żywych w tej partii tendencji nacjonalistycznych.

Rozmowy pierwszych siedmiu rund rozmów pełnomocników, zawieszone w czerwcu 1989 roku - nie doprowadziły do osiągnięcia satysfakcjonującego rozwiązania, choć wiele spraw udało się wyjaśnić, np. kwestię opieki nad grobami niemieckimi w Polsce, utworzenie pawilonu niemieckiego w Oświęcimiu, upamiętnienie miejsc związanych z niemieckim antyhitlerowskim ruchem oporu. Jednak wiele niejasności pozostawało w sprawach istotnych dla obydwu stron. Spośród oczekiwań Warszawy najważniejsze były kwestie finansowe (uregulowanie spłat kredytu "Jumbo", stanowisko RFN w polskich negocjacjach z Klubem Paryskim, udzielenie przez rząd RFN gwarancji kredytowych), dla RFN ważne były kwestie związane ze statusem i prawami mniejszości niemieckiej w Polsce. Po utworzeniu rządu Tadeusza Mazowieckiego stronę polską w negocjacjach pełnomocników reprezentował Mieczysław Pszona. MSZ, przygotowując dla niego notatkę przed kolejną turą negocjacji, zwracało uwagę na to, że: „Ze względu na zdecydowanie negatywne stanowisko władz RFN w sprawie uregulowania problemu odszkodowań dla polskich ofiar prześladowań nazistowskich brak jest szans realizacji tego postulatu $\mathrm{w}$ ramach negocjowanego "pakietu«. Spowodowałoby to bowiem w konsekwencji zablokowanie całości rozmów" ${ }^{\prime \prime}$. RFN konsekwentnie odmawiała rozmów na temat odszkodowań indywidualnych, poza pewnymi wyjątkami, takimi jak odszko-

\footnotetext{
8 Ibidem.

9 Uwagi i propozycje w związku z VIII rundą rozmów pełnomocników szefów rządów PRL i RFN, M. Pszczona i H. Teltschika, (14-19 września 1989), w: Polska wobec zjednoczenia Niemiec 1989-1991. Dokumenty dyplomatyczne. red. W. Borodziej, Warszawa 2006, s. 11.
} 
dowania dla ofiar eksperymentów pseudomedycznych ${ }^{10}$. Niemniej jednak w 1989 roku, nie bez związku ze zbliżającą się rocznicą wybuchu II wojny światowej, na konieczność uregulowania problemu odszkodowań wobec Polaków zaczęła zwracać uwagę opozycja w RFN. W przypadku "Zielonych”, projekty uregulowania tych zagadnień były zgłaszane od 1985 roku. 6 czerwca 1989 frakcja „Zielonych” w Bundestagu przedłożyła trzy wnioski: projekt ustawy o federalnej fundacji „odszkodowanie za nazistowską prace przymusową”, wniosek „Inicjatywy polityczne i prawne rządu federalnego wobec korzystających z pracy przymusowej", według którego rząd RFN powinien oddziaływać na firmy, które korzystały z pracy przymusowej lub ich następców prawnych, aby podjęły świadczenia na rzecz byłych robotników, oraz wniosek dotyczący „Indywidualnego odszkodowania dla byłych polskich robotników przymusowych $\mathrm{z}$ okresu panowania nazistowskiego w drodze umowy globalnej"11. Także stanowisko SPD zaczęło po 1985 roku ulegać zmianie, mimo to nie podjęła ona współpracy z „Zielonymi”, a przedstawiła w czerwcu 1989 własny projekt ustawy o utworzeniu fundacji „Odszkodowania za bezprawie nazistowskie”, obejmujący różne kategorie poszkodowanych, w tym np. więźniów obozów koncentracyjnych, poszkodowanych na skutek stosowania eutanazji, kobiety zmuszone do przerwania ciąży, homoseksualistów, prześladowanych komunistów, osób uchylających się od służby wojskowej. Wniosek nie obejmował zaś robotników przymusowych; sugerowano, aby dla zaspokojenia ich roszczeń stworzyć odrębny fundusz ${ }^{12}$.

Symbolem nowego otwarcia w stosunkach wzajemnych miała być wizyta kanclerza Helmuta Kohla w Polsce, zaplanowana na listopad 1989 roku. Przed wizytą zakończyły się rozmowy pełnomocników

${ }^{10}$ Szerzej na ten temat, m.in.: W. Jarząbek: Władze Polskiej Rzeczpospolitej Ludowej wobec problemu reparacji i odszkodowań od Republiki Federalnej Niemiec 1953-1989, „Dzieje Najnowsze" 2005, nr 2; Problem reparacji, odszkodowań $i$ świadczeń w stosunkach polsko-niemieckich 1944-2004, t. 1: Studia, t. 2: Dokumenty, red. S. Dębski i W.M. Góralski, Warszawa 2004.

${ }^{11}$ AAN KC PZPR, WZ 973/85, Notatka dotycząca inicjatyw legislacyjnych (z 6 czerwca 1989) partii "Zielonych" w sprawie odszkodowań dla ofiar prześladowań faszystowskich, oprac. J. Barcz.

${ }_{12}$ AAN KC PZPR, WZ 973/85, Notatka dotycząca inicjatywy SPD (z 21 czerwca 1989) na forum Bundestagu nt. utworzenia fundacji - „Odszkodowanie za bezprawie nazistowskie", oprac. J. Barcz. 
rządów (IX runda) i przygotowano tekst „Wspólnego Oświadczenia” premiera Polski i kanclerza RFN. Rezultat rozmów był kompromi$\mathrm{sem}^{13}$. Strona niemiecka zgodziła się na uruchomienie gwarancji kredytowych dla „wspólnie wybranych i sprawdzonych projektów”, część zobowiązań z kredytu "Jumbo" miała być umorzona, a reszta zamieniona na złotówki w celu realizowania wspólnych projektów. Strona polska nie zgodziła się na stosowanie określenia „Niemcy w Polsce” oraz na specjalne uregulowanie zagadnień dotyczących „obywateli polskich pochodzenia niemieckiego", na co zgodziły się Węgry w 1987 roku. Za swój sukces Warszawa uznała to, że udało się uniknąć specjalnego rozwiązania dwustronnego ani, jak to zaznaczono: „nie przyjęliśmy postanowień jednostronnie wiążących stronę polską - wszystkie postulaty adresowane są w jednakowej mierze do Polski i RFN"14. Warszawa była usatysfakcjonowana tym, jak to ujęto w notatce, że mimo „początkowo znacznych zastrzeżeń po stronie RFN", Układ z 7 grudnia 1970 roku, $\mathrm{w}$ tym zawarte $\mathrm{w}$ jego preambule sformułowania dotyczące nienaruszalności i poszanowania granic państwowych w ich kształcie, został uznany za podstawę stosunków wzajemnych. Warszawa za swój sukces uznawała to, że nie powoływano się, choć takie postulaty zgłosiło Bonn, na dokumenty odzwierciedlające niemieckie pozycje prawne, tzn. rezolucję Bundestagu z 1972 roku i orzeczenia Federalnego Trybunału Konstytucyjnego, podkreślające, że wszelkie decyzje RFN podejmowała we własnym imieniu, a nie Niemiec jako całości.

Przed IX turą rozmów, w czasie spotkania przygotowawczego z Uwe Kaestnerem Jerzy Sułek próbował powrócić do kwestii odszko-

${ }^{13}$ AMSZ, Dep. IV, z. 32/92, w. 1, Sprawozdanie z IX-tej rundy rozmów pełnomocników szefów rządów PRL i RFN M. Pszona i H. Teltschika (Bonn, 2-3 października br.), M. Pszon, 7 września 1989 r. Fragmenty notatki zostały opublikowane w: M. Tomala: Polityka i dyplomacja polska wobec Niemiec, t. 2: 1971-1990, Warszawa 2006, s. 649 i n. Nie zaznaczono, w jaki sposób autor ingerował w tekst, dokonując skrótów.

${ }^{14}$ Do uzgodnionego „Wspólnego Oświadczenia”, które miało wieńczyć wizytę kanclerza wprowadzono więc sformułowanie, iż: „obie strony umożliwią utrzymanie i rozwijanie kulturalnej tożsamości osobom i grupom ludności, które się przyznają do języka, kultury lub przynależności narodowej drugiej strony". Podstawą zobowiązań dwustronnych miały zaś być wielostronne zobowiązania podpisane przez obydwie strony, np. Powszechna Deklaracja Praw Człowieka ONZ, Międzynarodowy Pakt Praw Obywatelskich i Politycznych, postanowienia Aktu Końcowego KBWE z 1975 roku oraz dokumentów końcowych konferencji KBWE w Madrycie i Wiedniu. 
dowań dla polskich ofiar, proponując jednorazowe, niezbyt wysokie wypłaty (1-2 tys. DM) lub powołanie fundacji, ale - jak zapisał w notatce podsumowujacej - ,,i tym razem spotkaliśmy się ze stanowczą odmową i brakiem gotowości do omówienia sprawy"15.

Warszawa chciała, aby jeszcze przed wizytą kanclerza w Polsce ustalono konkretne liczby dotyczące poziomu gwarancji oraz konwersji kredytu „Jumbo" i aby kwestia ta była zawarta w liście kanclerza Kohla do premiera Mazowieckiego. Tuż przed wizytą kanclerza w Polsce, H. Teltschik poprosił polskiego chargé d'affaire Marka Jędrysa o przekazanie do kraju, że ,[...] zakres wkładu finansowo-gospodarczego Bonn w »pakiet«, który - zdaniem T. stawia RFN na pierwszym miejscu wśród państw zachodnich gotowych wesprzeć Polskę. Niepokoi ich $\mathrm{w}$ tej sytuacji eksponowanie $\mathrm{w}$ naszych mediach, ale i w wypowiedziach oficjalnych, a także $\mathrm{w}$ liście prezydenta W. Jaruzelskiego do Weizsäckera, kwestii odszkodowań oraz granicy na Odrze i Nysie. Obawiają się, że może to doprowadzić do rozbudzenia tuż przed wizytą oczekiwań, których Kohl nie będzie w stanie spełnić"16. Jędrys miał odpowiedzieć „,[...] iż strona RFN nie może oczekiwać zaniechania przez nas dziś, ani w przyszłości stawiania obu wymienionych przez T. kwestii, których ciężar gatunkowy i znaczenie dla procesu porozumienia są ewidentne" ${ }^{\prime 17}$. Zwrócił też uwagę, że w przypadku granicy dyskusja toczy się w Niemczech, a nie w Polsce.

Wizyta kanclerza Kohla rozpoczęła się 9 listopada. W związku z upadkiem muru berlińskiego została przerwana do 12 listopada. W czasie pierwszej rundy rozmów z premierem Mazowieckim, kanclerz wyraził swoje poparcie dla reform w Polsce. Kwestie związane $\mathrm{z}$ transformacją $\mathrm{w}$ Polce, kłopotami gospodarczymi, pomocą ze strony państw zachodnich i ze strony RFN zajmowały proporcjonalnie więcej miejsca także w późniejszej fazie rozmów ${ }^{18}$. Premier Mazowiecki

\footnotetext{
${ }^{15}$ Sprawozdanie z IX-tej rundy rozmów pełnomocników szefów rządów PRL i RFN M. Pszona i H. Teltschika...., op. cit.

${ }^{16}$ AMSZ, Dep. IV, z. 32/92, w. 1, szyfrogram z Kolonii, Jędrys do Kulskiego, 8 listopada 1989.

${ }^{17}$ Ibidem.

${ }^{18}$ Zapis rozmowy w "cztery oczy” premiera Mazowieckiego z kanclerzem Kohlem, notatki z 9, 10 i 14 listopada 1989, w: Polska wobec zjednoczenia Niemiec..., s. 158 i n.
} 
już w trakcie pierwszego spotkania chciał rozmawiać także na temat granicy na Odrze i Nysie Łużyckiej oraz cywilnoprawnych odszkodowań lub zadośćuczynienia dla polskich ofiar okupacji niemieckiej i robotników przymusowych. Kanclerz powiedział, że RFN nie ma roszczeń terytorialnych wobec Polski, niemniej dodał także, że: „Żaden rząd niemiecki nie może dziś uznać granicy Odra-Nysa w imieniu całych Niemiec, które dopiero powstaną w przyszłości. Rząd Kohla przyznaje prawo do stron ojczystych ludności polskiej, która urodziła się na tych terenach po 1945 r. Ale nie wolno oczekiwać, że położy ostateczny stempel (rezygnacji z tych ziem), takie oczekiwanie byłoby fałszywe. Kiedy ruch osobowy stanie się masowy, problem granicy straci na ostrości. Nie wolno codziennie podnosić sprawy granicy Odra-Nysa"19. Kohl przyznał, że istnieje problem roszczeń indywidualnych i obiecał się zastanowić nad sposobem jego rozwiązania, aczkolwiek odrzucił możliwość wypłaty regularnych odszkodowań, tłumacząc to głównie tym, że w Polsce żyje zbyt wiele ofiar i byłoby to nadmiernie kosztowne dla Bonn. W rozmowach prowadzonych 14 listopada, kanclerz, odwoływałując się do stanowiska prawnego RFN, negatywnie ustosunkował się do zgłoszonej 9 listopada propozycji Mazowieckiego, aby do „Wspólnego Oświadczenia", w części dotyczącej granicy, wprowadzić fragment z oświadczenia Bundestagu z 8 listopada 1989, w którym mówiono m.in. o tym, że koła historii nie da się cofnąć, a naród polski powinien wiedzieć, że jego prawo do życia w bezpiecznych granicach nie będzie kwestionowane przez Niemców poprzez roszczenia terytorialne ani teraz, ani w przyszłości. Oświadczenie to powtarzało fragment wystąpienia ministra spraw zagranicznych RFN Hansa-Dietricha Genschera na forum ONZ 27 września 1989 roku $^{20}$. Ani H. Kohl, ani H. Teltschik nie opisali $\mathrm{w}$ swoich wspomnieniach szczegółów rozmowy z premierem Mazowieckim ${ }^{21}$.

Po stronie polskiej pozostało uczucie niedosytu, związane głównie z wyraźną rezerwą strony niemieckiej do złożenia jednoznacznej dekla-

${ }^{19}$ Ibidem, s.162.

${ }^{20}$ D. Bingen: op. cit., s. 241-242.

${ }^{21}$ H. Kohl: Pragnątem jedności Niemiec, tłum. H. Dutkiewicz, Warszawa 1996; H. Teltschik: 329 dni. Zjednoczenie Niemiec w zapiskach doradcy kanclerza, tłum. R. Drecki i M. Struczyński, Warszawa 1992. 
racji w sprawie traktowania granicy na Odrze i Nysie Łużyckiej. Warto $\mathrm{w}$ tym miejscu przypomnieć, że Układ o podstawach normalizacji stosunków między PRL i RFN z 7 grudnia 1970 roku uznawał granicę na Odrze i Nysie za zachodnią granicę Polski, ale wkrótce po jego podpisaniu w RFN zaczęły się pojawiać głosy, że nie jest to ostateczne uznanie granicy. W grudniu 1971 rząd RFN ogłosił Memorandum, w którym dokonano interpretacji układu. Zaznaczano w nim m.in., że rząd RFN podpisał go we własnym imieniu i układ nie może wiązać przyszłego rządu zjednoczonych Niemiec ${ }^{22}$. W Memorandum nie znalazło się zaś sformułowanie układu mówiące o tym, że strony nie mają wobec siebie roszczeń terytorialnych i nie będą ich wysuwać także w przyszłości. Z prawnego punktu widzenia istniały wątpliwości, gdyż w dokumentach konferencji poczdamskiej przewidziano, że decyzje graniczne zostaną zatwierdzone w peace settlement (regulacji pokojowej). Ale i tak, jak przypominał Jan Barcz, zgodnie z pozycją prawną RFN Układ Poczdamski był traktowany przez RFN jako res inter alios acta i w związku $\mathrm{z}$ tym niewiążący dla RFN ${ }^{23}$. Wprawdzie w tym czasie trudno było znaleźć zwolenników zmian granicznych w Europie, ale z drugiej strony zmiany takie się dokonywały, chociażby w związku z rozpoczynającą się dezintegracją ZSRR i zgłaszaniem przez republiki związkowe pewnych aspiracji do większej samodzielności, a z czasem do niepodległości. Dlatego Warszawie zależało, aby w polsko-niemieckich stosunkach dwustronnych nie było wątpliwości prawnych odnośnie do charakteru granicy na Odrze i Nysie Łużyckiej.

\section{Od planu Kohla do konferencji 2+4}

Trudno więc się dziwić, że ogłoszenie przez kanclerza Kohla 10-punktowego planu zjednoczenia Niemiec wzbudziło w Warszawie zaniepokojenie. Jak to wówczas ujmowała strona polska, brakowało w nim bowiem 11. punktu, tzn. punktu odnoszącego się do granicy ${ }^{24}$.

\footnotetext{
${ }^{22}$ Na ten temat zob. W. Jarząbek: Władze PRL..., s. 41-42.

${ }^{23}$ J. Barcz: Udział Polski w konferencji "2+4". Aspekty prawne i proceduralne, Warszawa 1994, s. 20-21.

${ }^{24}$ Nie chodziło jedynie o "fizyczny brak" deklaracji w tej sprawie, ale o to, że wraz $\mathrm{z}$ ogłoszeniem tego planu przez urzędującego kanclerza stało się oczywiste, iż RFN
} 
Do Warszawy docierały też informacje na temat wypowiedzi kanclerza Kohla w sprawie granicy. Na przykład jego dementi wobec wypowiedzi rzecznika Wspólnoty Europejskiej, który powiedział, że kanclerz w czasie rozmów w Strasburgu oznajmił, iż zmiany granicy na Odrze i Nysie nie wchodzą rachubę $e^{25}$.

Zjednoczenie Niemiec interesowało Warszawę nie tylko w kontekście uznania granicy i miejsca RFN na scenie międzynarodowej. Istotna była również sprawa sukcesji umów i zobowiązań zaciągniętych przez NRD, m.in. w stosunkach gospodarczych z Polską. Warszawa bacznie obserwowała także rozwój wydarzeń w NRD, w tym przejawy niezadowolenia społecznego ${ }^{26}$. Wprawdzie 22 stycznia 1990 roku Polska, podobnie jak inne kraje bloku wschodniego, otrzymała od rządu NRD Memorandum, w którym za zasadniczy element bezpieczeństwa europejskiego i stabilności w stosunkach Wschód-Zachód uznawano istnienie $\mathrm{NRD}^{27}$, ale zarówno procesy wewnętrzne w NRD (rozmowy władza-opozycja), jak i proces przełamywania podziału Niemiec ulegały przyspieszeniu.

W tym czasie Warszawa próbowała rozwinąć akcję dyplomatyczną $\mathrm{w}$ celu zaprezentowania swoich interesów związanych ze zjednoczeniem Niemiec. Głównym zadaniem stało się doprowadzenie do jednoznacznego i ostatecznego uznania polskiej granicy zachodniej. Rozmawiano na ten temat z przedstawicielami dyplomatycznymi państw zachodnich, był to jeden z głównych tematów poruszanych przez premiera Mazowieckiego w czasie rozmów w Londynie 12 lutego. Margaret Thatcher podzielała pewne obawy Warszawy, popierała koncepcje jednoznacznego uznania przez Niemcy granicy na Odrze i Nysie w formie traktatu, a także wzmocnienie tego faktu przez deklarację wielostronna, np. wydaną przez ONZ. Na pytanie Mazowieckiego, czy poparłaby koncepcje podpisania traktatu pokojowego, dotyczącego kwestii

i jej rząd przejmują polityczną odpowiedzialność za proces jednoczenia Niemiec, co nadawało dodatkowy odcień wszelkim deklaracjom rządowym, jak pisał A. Hajnicz w: idem: Ze soba czy przeciw sobie. Polska-Niemcy 1989-1992, Warszawa 1996, s. 79.

${ }^{25}$ AMSZ, Dep. III, z. 2/94, w. 10, Wypowiedź H. Kohla w sprawie granicy na Odrze i Nysie, PAZ 9 grudnia 1990.

${ }^{26}$ Na temat wydarzeń w NRD m.in.: T. Jaskułowski: Pokojowa rewolucja w Niemieckiej Republice Demokratycznej w latach 1989-1990. Geneza - przebieg - efekty, Wrocław 2007.

${ }^{27}$ AMSZ, Dep. IV, 14/94, w. 2, Memoranum, 22 stycznia 1990. 
granicznych, premier odpowiedziała, że tak. Dodała też: „[...] musimy działać szybko, bo coraz więcej ludzi mówi, że zjednoczenie jest dobre. Stąd trzeba otwarcie powiedzieć, że ceną zjednoczenia jest uznanie przez Niemcy granic"'28.

W dniu 13 lutego 1990 roku w czasie konferencji „otwartego nieba” w Ottawie ogłoszono kluczową decyzję dotyczącą jednoczenia Niemiec - proces ten miał przyjąć formę konferencji pomiędzy dwoma państwami niemieckimi i czterema państwami okupującymi Niemcy po wojnie. W pierwotnej wersji komunikatu, przedstawionej ministrowi Krzysztofowi Skubiszewskiemu przez ministra Eduarda Szewardnadze, zastosowano dość ogólną formułę odnoszącą się do aspektów zewnętrznych zjednoczenia. Polski minister wnioskował więc, aby określenie zadań konferencji obejmowało też interesy sąsiadów i zaproponował formułę „łącznie z kwestiami bezpieczeństwa państw sąsiadujących", co nastąpiło $^{29}$. Według tego, co przekazał Skubiszewski do Warszawy, „Sekretarz Stanu Baker powiedział mi, że były »pewne trudności« w przyjęciu mojej formuły. Jednak rozmowy $z$ ministrami czterech mocarstw dały rezultat $^{\prime 30}$. Z depeszy wynika, że w rozmowach dwustronnych ministrowie James Baker, Roland Dumas, Douglas Hurd i Eduard Szewardnadze nie zgłosili sprzeciwu wobec tego uzupełnienia.

Warszawa postanowiła przedstawić swoje stanowisko. W identycznie brzmiących listach wystosowanych do przywódców czterech mocarstw premier przypomniał, że: „W Republice Federalnej Niemiec wielokrotnie podkreślano wyłączność przyszłego traktatu pokojowego do uregulowania tej granicy [na Odrze i Nysie - W.J.]. [...] Oświadczam, że Polska jest gotowa uczestniczyć w pracach nad traktatem. Jednak z przyczyn od Polski niezależnych, prace nad traktatem pokoju albo nie są obecnie brane pod uwagę, albo są odkładane do nieokreślonego momentu po państwowym zjednoczeniu narodu niemieckiego, co pewnym siłom daje asumpt do stałego uważania granicy pol-

${ }^{28}$ Roboczy zapis rozmowy Prezesa Rady Ministrów Tadeusza Mazowieckiego z premierem Wlk. Brytanii i Ptn. Irlandii pania Margaret Thatcher, Londyn 12 luty 1990 r. w: Polska wobec zjednoczenia..., s. 197 i n.

${ }^{29}$ Komunikat z Ottawy, 13 lutego 1990 w: J. Barcz: op. cit., s. 113.

${ }^{30}$ Szyfrogram z Ottawy, Skubiszewski do Mazowieckiego, 13 lutego 1990, w: Polska wobec zjednoczenia..., s. 203. 
sko-niemieckiej jako sprawy otwartej. Nie możemy się zgodzić, aby po zjednoczeniu Niemiec ten stan rzeczy nadal się utrzymywał"31. Mazowiecki proponował więc podpisanie traktatu potwierdzającego trwałość istniejącej granicy, parafowanego przez dwa państwa niemieckie przed zjednoczeniem i podpisanego po zjednoczeniu oraz zapowiadał przedłożenie projektu traktatu, a także uznał za niezbędny udział Polski w dyskutowaniu zewnętrznych aspektów zjednoczenia. Wyjaśniał też, że Polska „nie zabiega o status identyczny ani z żadnym z czterech mocarstw, ani z żadnym z dwóch państw niemieckich" ${ }^{32}$. Niemniej odbiór listu był inny - w USA zrozumiano go jako wyrażenie przez Polskę aspiracji do bycia piątym mocarstwem ${ }^{33}$.

Istotną rolę w kształtowaniu polityki Zachodu wobec procesu zjednoczenia Niemiec odgrywały Stany Zjednoczone. Wydaje się, że strona amerykańska starała się przekonać kanclerza Kohla do uczynienia jasnej deklaracji w sprawie granic ${ }^{34}$. Próby takie, według relacji uczestników, podejmowano w czasie spotkania w Camp David w końcu lutego 1990 roku. Niemniej szczególnie ważne dla USA były wybory strategiczne RFN, to, czy zjednoczone Niemcy nie będą próbowały rozluźnić lub zerwać swoich więzów z zachodnimi strukturami wojskowymi i politycznymi w zamian za zgodę ZSRR na zjednoczenie. W tym czasie ZSRR był przeciwny przynależności RFN do NATO po zjednoczeniu. Strona amerykańska, zapraszając kanclerza do Camp David, chciała też w pewnym sensie dowartościować $\mathrm{H}$. Kohla, gdyż żaden z kanclerzy niemieckich nie składał wcześniej wizyty w tym miejscu. Starała się również o to, aby spotkanie upłynęło $\mathrm{w}$ miłej atmosferze, $\mathrm{np}$. sekretarz stanu James Baker przywitał Kohla na lotnisku ubrany we flanelową koszulę i w butach kowbojskich. W czasie rozmów Kohl miał dać do zrozumienia, że według niego granica nie stanowi dużego problemu. Oczekiwał też najwyraźniej, że to cztery mocarstwa podejmą w tej sprawie decy-

${ }^{31}$ List Prezesa rady Ministrów RP Tadeusza mazowieckiego skierowany do Prezydenta Republiki Francuskiej Françoisa Mitteranda, w: J. Barcz: op. cit., s. 114-115.

${ }^{32}$ Ibidem, s. 116.

${ }^{33}$ Por. Ph. D. Zelikow, C. Rice: Germany United and Europe Transformed. A Study in Statecraft, Harvard University Press 1995, s. 216 i n.

${ }^{34}$ Ibidem, s. 212 i n.; A. Stent: Russia and Germany reborn: Unification, the Soviet Collapse, and the New Europe, Princeton 1999, 118 i n. 
zję, a to oznaczałoby, że to nie on przesądził ostatecznie o utracie przez Niemcy terenów wschodnich. Strona Polska nie była pewna co do wyników spotkania w Camp David. Ważne było to, że USA nie udzieliły oficjalnie poparcia dla polskiego wniosku w sprawie włączenia się w rozmowy $2+4$, choć mówiono o potrzebie wypracowania mechanizmu konsultacji z Polską. Ambasada polska na podstawie rozmów toczonych w Waszyngtonie przekazała, że brak wyraźnych nacisków na kanclerza mógł wynikać z tego, że „celem Busha było udzielenie poparcia Kohlowi w jego walce wyborczej z socjaldemokratami. USA oceniają bowiem, iż $\mathrm{w}$ przypadku zwycięstwa socjaldemokracji nasilą się tendencje przeciw obecności USA w Niemczech oraz nastroje neutralizmu, które widziane są jako sprzeczne $\mathrm{z}$ długofalowymi interesami USA"35.

Dyplomacja polska starała się także prowadzić akcję informacyjną w amerykańskim Senacie i Izbie Reprezentantów. Efektem tych zabiegów było wystosowanie przez grupę 34 senatorów 2 marca depesz do Helmuta Kohla i Hansa Modrowa, w których popierała polską propozycję parafowania układu potwierdzającego granicę i podpisania go po zjednoczeniu ${ }^{36}$. Jak zauważała Warszawa, dominowali demokraci, republikanie byli reprezentowani jedynie przez cztery osoby, co według ambasadora Jana Kinasta mogło być skutkiem nacisku administracji Busha. Do pozyskiwania strony amerykańskiej dla polskich racji włączyła się również Polonia. Zorganizowano akcję wysyłania listów, telegramów i faksów do Białego Domu. Jan Nowak-Jeziorański powiedział mi, że dzwoniono do niego z Białego Domu z prośba, aby powstrzymać akcję, bo zablokowano faksy ${ }^{37}$. Ambasada szacowała, że do 28 lutego wpłynęło ok. 160 tys. listów i depesz ${ }^{38}$. W prasie amerykańskiej, w tym w „The Washington Post”, pojawiły się głosy krytykujące stosunek Helmuta Kohla do granicy i nawoływały administrację amerykańską do nacisków na kanclerza. Pojawiły się też komentarze, że niejasne stanowi-

${ }^{35}$ AMSZ, Dep. III, z. 35/94, w. 2, Szyfrogram z Waszyngtonu, Kinast do Duchowskiego, 27 lutego 1990.

${ }^{36}$ AMSZ, Dep. III, z. 35/94, w. 2, Szyfrogram z Waszyngtonu, Kinast do Duchowskiego, 2 marca 1990.

${ }^{37}$ Wywiad W. Jarząbek z J. Nowakiem-Jeziorańskim w lipcu 1996 r. w Annadale.

${ }^{38}$ AMSZ, Dep. III, z. 35/94, w. 2, Szyfrogram z Waszyngtonu, Kinast do Duchowskiego, 28 lutego 1990. 
sko w sprawie granicy na Odrze i Nysie Łużyckiej sprawia, iż został zahamowany proces emancypowania się Polski spod wpływów ZSRR, a rząd Polski został zmuszony do zatrzymania Armii Czerwonej w Polsce ${ }^{39}$. Wiedziano wówczas, że Węgry i Czechosłowacja przedstawiły Moskwie sugestię wycofania Armii Czerwonej z ich terytoriów, na co Gorbaczow się zgodził, ale nie chciała tego Polska. Na spotkaniu w sowieckim Sztabie Generalnym 29 stycznia 1990 roku, strona polska potwierdziła, że nie domaga się wyjazdu Armii Czerwonej z Polski ${ }^{40}$. W „Gazecie Wyborczej” 14 lutego 1990 ukazał się zaś artykuł, w którym dalszą obecność Armii Czerwonej w Polsce uzasadniano względami równowagi sił w zmieniającej się Europie oraz tym, że dla Polski może to być argument przetargowy w rozmowach ${ }^{41}$.

Odwołując się do tradycyjnego, w pewnym sensie stereotypowego podejścia do polityki europejskiej, co nie znaczy, że całkowicie nieuzasadnionego, wiele nadziei Warszawy kierowanych było pod adresem Paryża. Warszawa liczyła na to, że Francja będzie zainteresowana, aby zjednoczenie Niemiec odbyło się na takich zasadach, które nie osłabią zbyt pozycji Francji w Europie. Paryż i Bonn były motorem integracji europejskiej. Niemcy były silniejsze ekonomicznie, ale Francja dysponowała siłami nuklearnymi. W koncepcjach francuskich, proces integracji europejskiej traktowany był także w kategoriach bezpieczeństwa narodowego. Miał służyć uniknięciu sytuacji, w której Niemcy zdecydowałyby się na poszukiwanie dla siebie innej drogi niż bliski sojusz z państwami zachodnimi ${ }^{42}$. Francja nie była zainteresowana zmianami terytorialnymi w Europie. Gdy w czasie jednego z oficjalnych obiadów w Paryżu pod koniec 1989 roku rzecznik rządu niemieckiego powiedział: „Who can contest that Silesia is a German territory?", dyplomaci francuscy $\mathrm{w}$ rozmowach $\mathrm{z}$ partnerami zachodnimi mieli przypominać

${ }^{39}$ AMSZ, Dep. III, z. 35/94, w. 2, Szyfrogram z Waszyngtonu, Kinast do Duchowskiego, 10 marca 1990.

${ }^{40}$ Czechoslovak Report on a Meeting at the Soviet General Staff (fragmenty), w: A Cardboard Castle? An Inside History of the Warsaw Pact 1955-1991, red. V. Mastny i M. Byrne, Budapest 2005, s. 667.

${ }^{41}$ J. Reiter: Po co te wojska?, "Gazeta Wyborcza” z 14 lutego 1990.

${ }^{42} \mathrm{Na}$ takie motywy polityki francuskiej wskazywał m.in. H. Védriné: Les Mondes de François Mitterand. A l'Élysée, Paris 1988, s. 416. 
o tej wypowiedzi podawanej również jako przykład nadal obecnych dążeń niemieckich do rewizji granic ${ }^{43}$.

W Warszawie liczono na to, że Francja - zgodnie $\mathrm{z}$ udzielanymi wcześniej deklaracjami - popiera ostateczny charakter granicy na Odrze i Nysie Łużyckiej i strona polska uzyska wsparcie Francji w swoich aspiracjach do uczestniczenia $\mathrm{w}$ jakiejś formie $\mathrm{w}$ konferencji $2+4$ oraz poprze polski postulat podpisania traktatu regulującego charakter granicy. I tak się stało. Charakterystyczne jest to, że zarówno Wielka Brytania, jak Francja i USA poddawane były tej samej akcji propagandowej ze strony Bonn. Próbowano mianowicie wskazywać, że Warszawa domaga się podpisania traktatu pokojowego z Niemcami nie tylko dlatego, że jest zainteresowana uzyskaniem ostatecznego potwierdzenia granicy, ale dlatego, że chce uzyskać od Niemiec reparacje. Był to dość nośny argument, w dodatku wydawał się prawdopodobny, gdyż Warszawa była $\mathrm{w}$ trudnej sytuacji ekonomicznej. O problem reparacji pytała premiera Mazowieckiego premier Thatcher w czasie rozmów w Londynie. Także w czasie rozmów z prezydentem Bushem kanclerz Kohl mówił o tym, że gdyby doszło do rozmów na temat podpisania traktatu pokojowego, Polska wystąpiłaby z roszczeniami reparacyjnymi i odszkodowawczymi. W świetle tego, że Warszawa od lat domagała się nie wypłaty reparacji, a odszkodowań, i to głównie dla robotników przymusowych, kanclerz musiał zdawać sobie dobrze z tego sprawę, szczególnie po rozmowach z T. Mazowieckim. Musiał też wiedzieć, że w przypadku ofiar pochodzących z państw zachodnich czyniono rozróżnienie między reparacjami (świadczeniami wypłacanymi państwom) a odszkodowaniami indywidualnymi. W przypadku Polski RFN chciała włączyć świadczenia indywidualne do problemu reparacji, korzystając z tego, że w 1953 roku w nie do końca wyjaśnionych okolicznościach Warszawa zrzekła się reparacji od Niemiec. W rozmowie z G. Bushem i być może też $\mathrm{w}$ innych rozmowach, RFN uczyniła też zręczny zabieg, polegający na tym, że Kohl poinformował, iż RFN wypłaciła 150 miliardów DM Polsce, Izraelowi i indywidualnym poszkodowanym ${ }^{44}$. Wymienienie

${ }^{43}$ Ph. D. Zelikow i C. Rice: op. cit., s. 206.

44 "Kohl feared that the Poles might use such participation to hold a settlement hostage to demands for reparations - more compensation for Poland for war time damage 
w pierwszej kolejności Polski (jeśli tak rzeczywiście było, a to sugeruje nie tylko zapis w cytacie, ale także kontekst wypowiedzi - chodziło o to, aby Polska nie wzięła udziału w rozmowach $2+4$ ), jest być może wyrazem dyplomatycznych zdolności, ale też nieuczciwości. Także rozmówcom francuskim strona niemiecka mówiła o tym, że Warszawa będzie domagała się reparacji. Dyplomaci francuscy przekazywali tę informację swoim polskim rozmówcom ${ }^{45}$. Z drugiej strony próbowali również wyjaśniać stronie niemieckiej stanowisko polskie, w tym wskazywać na źródła polskiej wrażliwości oraz informowali ją o popieraniu polskiego postulatu, aby w sposób oficjalny Warszawa była konsultowana co do pewnych aspektów zjednoczenia ${ }^{46}$. W czasie jednej z rozmów dyrektor ds. niemieckich w MSZ Francji Denis Quauer wyrażał zrozumienie dla postulatów Warszawy, mówił o konieczności stworzenia prawnych gwarancji, że zjednoczone Niemcy obejmą jedynie obydwa państwa niemieckie. Twierdził też, iż granica na Odrze i Nysie powinna być potwierdzona zarówno gwarancjami udzielonymi w ramach konferencji 2+4, jak też podczas szczytu KBWE, który był przewidywany na jesień 1990 w Paryżu. Jak zaznaczano w polskich dokumentach, gdy strona niemiecka zdecydowanie odrzuciła możliwość parafowania układu o granicy przed faktycznym zjednoczeniem, wówczas minister Roland Dumas miał zasugerować Warszawie, aby łączyła kwestię uznania granicy z zachowaniem szczególnych uprawnień mocarstw na terenie Niemiec.

W Bonn zdawano sobie sprawę z tego, że Paryż jest zaniepokojony brakiem niemieckich deklaracji dotyczących granicy. Wydaje się, że wydanie przez Bundestag rezolucji w sprawie granicy 8 marca, czyli $\mathrm{w}$ przeddzień rozpoczynającej się 9 marca oficjalnej wizyty prezydenta W. Jaruzelskiego i premiera T. Mazowieckiego w Paryżu, nie było przypadkowe. W czasie rozmów strona francuska potwierdziła, że według niej zjednoczenie Niemiec nie będzie możliwe bez potwierdzenia, że granica jest ostateczna. K. Skubiszewski w notatce $\mathrm{z}$ wizyty napisał:

done by the Third Reich. Germany Kohl explained, had already paid DM 150 billions to Poland, Israel and individual claimants", w: ibidem, s. 213.

${ }^{45}$ AMSZ, Dep. III, z. 35/94, w. 2, depesza z Paryża, Fijałkowski do Fekacza, 3 lutego 1990.

${ }^{46}$ T. Schabert: Wie Weltgeschichte gemact wird. Frankreich und die deutsche Einheit, Stuttgart 2002, s. 470. 
„Francja opowiada się stanowczo za nietykalnością granicy na Odrze i Nysie i wykorzysta środki pozostające w jej dyspozycji, aby to stanowisko forsować ${ }^{\prime \prime 7}$. Warszawa uzyskała też poparcie swojego celu, tzn. tego, aby uznanie granic miało charakter traktatu oraz wyraziła zainteresowanie, aby uzyskało ono także gwarancje czterech mocarstw, aczkolwiek zarezerwowała sobie prawo do wypowiedzenia się w przyszłości co do charakteru tych gwarancji. Francja poparła również dążenia Polski do uczestniczenia $\mathrm{w}$ rozmowach $2+4 \mathrm{w}$ tej części, która będzie dotyczyła granic i bezpieczeństwa zewnętrznego Polski. Strona francuska także zdradzała pewien niepokój odnośnie do tempa zjednoczenia, ale właściwie była przekonana, że przynajmniej kwestie graniczne będą rozwiązane i, jak można sądzić, widziała w polityce niemieckiej więcej gry taktycznej ${ }^{48}$.

Prezydent François Mitterand zademonstrował poparcie dla racji strony polskiej, uczestnicząc we wspólnej konferencji prasowej z polskimi gośćmi i mówiąc, że stanowisko francuskie idzie dalej niż deklaracja Bundestagu, oraz wyrażając pogląd, że cztery mocarstwa powinny wziąć odpowiedzialność za legalne zamknięcie problemu granicy. Było to odbierane jako poparcie polskiej koncepcji parafowania układu granicznego przed zjednoczeniem, a nawet jako poparcie koncepcji przedłużenia praw mocarstw po zjednoczeniu Niemiec do momentu prawnego rozwiązania problemu granicznego ${ }^{49}$. Prezydent poinformował również kanclerza Kohla, że Francja podziela polskie zdanie w sprawie konieczności podjęcia rozmów na temat traktatu granicznego przez zjednoczeniem. W swoich wspomnieniach Kohl napisał, że po rozmowie $\mathrm{z}$ francuskim przywódcą miał wrażenie, iż ożyła mała ententa oraz skarżył się, że niemieckie uczucia nie były brane pod uwagę $e^{50}$.

\footnotetext{
${ }^{47}$ Notatka informacyjna z oficjalnej wizyty prezydenta W. Jaruzelskiego i prezesa Rady Ministrów T. Mazowieckiego we Francji (9.03.1990), w: Polska wobec zjednoczenia..., s. 222 i n.

${ }^{48}$ Rozmowy Wandy Jarząbek z dyrektorem ds. politycznych MSZ Francji Bertrandem Dufourcq oraz Sophie-Caroline de Margerie, tłumaczącą z języka polskiego rozmowy prezydenta i premiera z prezydentem Mitterandem, Paryż, czerwiec 2006.

${ }^{49}$ H. Teltchik: op. cit., s. 141. Zdaniem niemieckiego ambasadora w Paryżu, prezydent Mitterand wystąpił jako „Defensor Poloniae” i nie wspomniał słowem o zmieniającym się charakterze współpracy między Polską i Niemcami. F. Pfeffer: Ein Amt und eine Meinung. Botschaftef in Polen und Frankreich, Frankfurt 2006, s. 347.

${ }^{50}$ H. Kohl: op. cit., s. 190-193.
} 
Rozmowy premiera Tadeusza Mazowieckiego w Waszyngtonie 21 i 22 marca 1990 roku zdawały się wskazywać, że konieczność formalnego uregulowania kwestii granicy i znalezienia dla Warszawy miejsca w rozmowach na temat zjednoczenia Niemiec - choć różnie to sobie wyobrażano - spotyka się ze zrozumieniem pięciu uczestników konferencji $2+4$. Jedynie RFN była temu nadal przeciwna. Prezydent Bush wyraził wprawdzie przekonanie, że Kohl rozumie potrzebę uznania granicy, ale stwierdził także, że był: „osobiście mocno rozczarowany jego meandrami w ostatnim czasie" ${ }^{51}$. Bush próbował mimo to uspokajać polskiego premiera i powtarzał, że kanclerzowi można ufać. Zarówno w czasie pierwszej rozmowy 21 marca, jak i w trakcie drugiej, 22 marca, Bush zwracał uwagę na to, że Niemcy nie chcą być oceniane przez pryzmat przeszłości. Powiedział też, że w Ottawie minister spraw zagranicznych RFN wypowiadał się również przeciwko udziałowi Włoch w konferencji 2+4. (RFN sprzeciwiała się także udziałowi Holandii). Zaproponował także podjęcie tajnych rozmów na temat traktatu granicznego. Bush próbował również tłumaczyć postępowanie Kohla wymogami polityki wewnętrznej, na co premier Mazowiecki odpowiedział, że te wyjaśnienia są męczące, a w Niemczech różne wybory są niemal ciągle. Kohl zaś „wzbudził we mnie [w T.M.] w ostatnim okresie pewne wątpliwości co do stopnia ulegania własnej prawicy" ${ }^{\prime 52}$. Powiedział też, że, jego zdaniem, Kohl będzie się starał wykorzystać do zjednoczenia artykuł 23 Konstytucji RFN - tak rzeczywiście było - i wyraził pogląd, że ów artykuł trzeba będzie usunąć z niemieckiej Ustawy zasadniczej. Zarówno w czasie rozmowy z prezydentem Bushem, jak i wcześniej w Londynie, premier Mazowiecki wypowiadał się przeciwko neutralizowaniu Niemiec. W Waszyngtonie Mazowiecki opowiedział się za pozostawieniem na terenie Niemiec Armii Czerwonej, tłumacząc to koniecznością udzielenia wsparcia M. Gorbaczowowi, głównie w wymiarze wewnętrznym. Zdaniem Busha, wojska ZSRR powinny się wycofać z tych krajów, które sobie tego zażyczą. Wiedziano wprawdzie, że Warszawa nie wyraziła zainteresowania wyjściem Armii Czerwonej z Polski, ale propozycja po-

\footnotetext{
${ }^{51}$ Zapis z rozmowy Prezesa Rady Ministrów Tadeusza Mazowieckiego z prezydentem USA Georgem Bushem, 30 marca 1990, w: Polska wobec zjednoczenia..., s. 241.

${ }^{52}$ Ibidem.
} 
zostawienia tej armii na terenie zjednoczonych Niemiec, jak i jej uzasadnienie, wywołały zdziwienie prezydenta ${ }^{53}$.

Warszawa szukała również wsparcia w mniejszych państwach europejskich. 2 marca 1990 roku w liście do państw sąsiadujących z obydwoma państwami niemieckimi, Warszawa przedstawiła swój punkt widzenia, wskazując, że komunikat z Ottawy, wspominający o konieczności uwzględnienia interesów bezpieczeństwa sąsiadów Niemiec, oznacza, iż $\mathrm{w}$ dyskusjach ministrów $\mathrm{w}$ ramach konferencji $2+4$ powinno być też miejsce dla ministrów z krajów ościennych ${ }^{54}$. Szczególnie zaś powinno się znaleźć miejsce dla Polski. Udziałem w konferencji była zainteresowana również Czechosłowacja. Listy wystosowano do ministrów Austrii, Belgii, Czechosłowacji, Danii, Holandii, Luksemburga, Szwajcarii. Niemniej sposób, w jaki miano doprowadzić do zjednoczenia Niemiec, sprawiał, że kluczowe było zdanie mocarstw i państw niemieckich.

Warszawa próbowała też wpływać na stanowisko Bonn. W dniach 5-8 lutego 1990 roku, w ramach periodycznych konsultacji na szczeblu ministrów spraw zagranicznych, z wizytą do RFN udał się Krzysztof Skubiszewski. Minister, zgodnie z reprezentowaną wówczas w Polsce linią polityczna, proponował, aby Aktowi Końcowemu KBWE nadać formę traktatu ${ }^{55}$. W ten sposób potwierdzono by także terytorialne status quo w Europie. Mimo to strona niemiecka była temu przeciwna. Warszawie trudno było zrozumieć sprzeciw RFN wobec uregulowania kwestii granicznych przed zjednoczeniem oraz niechęć do tego, aby Warszawa mogła uczestniczyć w części obrad konferencji 2+4. Z drugiej strony dostrzegano różnice zdań w samej RFN, w tym między kanclerzem i ministrem spraw zagranicznych H.-D. Genscherem, który początkowo nie wykluczał możliwości poszukania formy wypracowania traktatu granicznego przed zjednoczeniem ${ }^{56}$.

Ze zdumieniem zaś odebrano wypowiedzi, w których kanclerz Kohl zaczął łączyć sprawę uznania granicy z problemem mniejszości niemiec-

\footnotetext{
${ }^{53}$ Ph.D. Zelikow i C. Rice: op. cit., s. 221.

${ }^{54}$ List ministra spraw zagranicznych RP Krzysztofa Skubiszewskiego do ministrów spraw zagranicznych siedmiu państw sąsiadujących z NRD i RFN w: J. Barcz: op. cit., s. 120-123.

${ }_{55}$ Notatka informacyjna o wizycie oficjalnej Ministra Spraw Zagranicznych RP prof. K. Skubiszewskiego w RFN, 5 marca 1990.

${ }^{56}$ J. Barcz: op. cit., s. 31-32.
} 
kiej w Polsce oraz z rezygnacją Polski z reparacji wojennych. Wielu obserwatorów - i trudno się oprzeć wrażeniu, że słusznie - odbierało wypowiedzi kanclerza jako próbę obniżenia pozycji Warszawy w stosunkach międzynarodowych i pokazania jej jako państwa nieprzestrzegającego i niechcącego przestrzegać praw mniejszości. Do problemu tego ustosunkowali się zarówno rzecznik rządu polskiego, jak i premier T. Mazowiecki. W wywiadzie dla telewizji RFN, powtórzonym 4 marca przez telewizję Polską i wydrukowanym w „Rzeczpospolitej”, premier mówił m.in. o swoim zdumieniu takim stawianiem sprawy i dodawał: „Sprawę mniejszości wyraziliśmy we wspólnym oświadczeniu w czasie jego pobytu w Polsce i sądzę, że dotrzymujemy słowa [...]. Podkreślam, że myśmy wysuwali sprawę uregulowania granicy, jeśli chce się rozszerzać problematykę, możemy ją rozszerzyć. My też mamy coś do powiedzenia, np.: sprawa odszkodowań dla ludzi, którzy byli zmuszani do robót przymusowych w III Rzeszy. [...] Ja nie widzę powodu, dla którego przy dobrej woli nie można by dopracować rozwiązania traktatowego, które $\mathrm{w}$ moim przekonaniu powinno być parafowane po wyborach w NRD, a podpisane ostatecznie po zjednoczeniu. Nie widzę też powodu, dla którego obecność Polski w tej części rokowań miałaby komukolwiek przeszkadzać. Jest ona moralnie i historycznie uprawniona"57. Mazowiecki przedstawił też pogląd, że ówczesne wydarzenia były testem pojednania polsko-niemieckiego.

W tym czasie stosunki polsko-niemieckie były obserwowane i komentowane zarówno przez elity, jak i zwykłych obywateli. W prasie polskiej pojawiły się ostre tytuły i komentarze, najostrzejsze, odwołujące się do skojarzeń historycznych w „Trybunie”, np. Kohl wreszcie odsłonit przyłbice, Kohl strzela z "grubej Berty", Przejaw szaleństwa wielkoniemieckiego. Janusz Reiter pisał na początku marca w "Gazecie Wyborczej” o tym, że kanclerz prowadzi wobec Polski nieszczera, dwuznaczną grę. Oświadczenie w sprawie niedopuszczania Polski do rozmów w sprawie granicy wydali 9 marca polscy historycy, przywołując przykład braku Polski w czasie konferencji w Teheranie i Jałcie. Także episkopat poparł starania rządu o dopuszczenie Polski do stołu obrad ${ }^{58}$.

${ }^{57}$ Cyt. za: M. Tomala: Zjednoczenie Niemiec. Reakcje Polaków, Warszawa 2000, s. 93-94.

${ }^{58}$ Przegląd komentarzy m.in. ibidem, s. 82-85, 100-102. Zob. także: O. Osica: „Widmo Wielkich Niemiec". Proces jednoczenia państw niemieckich w polskiej literaturze naukowej 
Stanowisko przedstawione przez Bundestag w rezolucji przyjętej 8 marca 1990 roku nie zadowalało Warszawy. Wprawdzie Układ Warszawski z 7 grudnia 1972 roku został uznany za trwały fundament stosunków dwustronnych, deklarowano, że prawo narodu polskiego „do życia w bezpiecznych granicach nie będzie kwestionowane", ale przypominano też, że nie zawarto układu pokojowego i nie wymieniono z nazwy granicy na Odrze i Nysie Łużyckiej ${ }^{59}$.

Po wyborach demokratycznych w NRD i wyłonieniu nowego rządu, Warszawa chciała zapoznać się z jego opiniami na temat zjednoczenia Niemiec. Minister spraw zagranicznych NRD Markus Meckel podczas wizyty w Warszawie w dniu 23 kwietnia 1990 przekazał, że NRD bez zastrzeżeń potwierdza nienaruszalność granicy na Odrze i Nysie. „Min. M. Meckel poparł jednoznacznie naszą propozycję traktatowego potwierdzenia ostatecznego charakteru zachodniej granicy poprzez wynegocjowanie i parafowanie odpowiedniego traktatu z 2 państwami niemieckimi oraz podpisanie go i ratyfikowanie ze zjednoczonymi Niemcami. Zaznaczył, że z inicjatywy jego partii [M. w momencie wizyty był urzędującym przewodniczącym SPD] sprawa znalazła się w porozumieniu koalicyjnym poprzedzającym utworzenie rządu de Maizière. [...] Min. Meckel poparł udział Polski w rozmowach 2+4 w sprawach odnoszących się do naszej granicy zachodniej, jednak uczestnictwo Polski w dyskusjach nad problemem bezpieczeństwa uznał za »bardziej problematyczne $\ll^{\prime \prime 60}$.

Warszawa kontynuowała prace nad przygotowaniem traktatu uznającego przebieg granicy. Dokument został następnie przedstawiony obydwu państwom niemieckim w dniu 27 kwietnia oraz w trzy dni później czterem mocarstwom. $W$ maju rozpoczęły się trójstronne rozmowy między stroną polską i obydwoma państwami niemieckimi. Odbyły się trzy spotkania 3, 18 i 29 maja. RFN nie zmieniła swojego zdania na temat

i publicystyce w: P. Buras, P. Klimiuk i O. Osica: Niemcy w polskiej literaturze naukowej i publicystyce 1989-1996. Bibliografia, Warszawa 1997, s. 32-60.

${ }_{59}$ Tłumaczenie nieoficjalne rezolucji Bundestagu w: J. Barcz: op. cit., s. 33-34.

${ }^{60}$ AMSZ, Dep. IV, z. 14/94, w. 2, Notatka informacyjna o wizycie Ministra Spraw Zagranicznych Niemieckiej Republiki Demokratycznej Markusa Meckela w Warszawie w dniu 23 kwietnia 1990 r., 16 czerwca 1990 r. Notatka ta nie została rozesłana do osób wymienionych w rozdzielniku, gdyż jak wynika z odręcznej uwagi „zdezaktualizowała się" - została sporządzona w kilka tygodni po wizycie! 
parafowania układu przed zjednoczeniem, powołując się na problemy prawne i brak kompetencji do ustalenia tekstu traktatu. Według opinii profesora Jana Barcza „W sumie było to stanowisko polityczne. Wystarczy wskazać na fakt, ze rzekomy brak kompetencji nie przeszkodził RFN podpisać (a więc dokonać czynności bez porównania istotniejszej z punktu widzenia prawa międzynarodowego niż parafowanie) Traktatu o ostatecznej regulacji w odniesieniu do Niemiec, który zakończył konferencję »2+4« (sam traktat zawiera klauzulę, że ratyfikowany jest przez zjednoczone Niemcy i będzie je wiązał) [...]. Podobnie było w odniesieniu do Traktatu o dobrym sąsiedztwie, partnerstwie i współpracy między RFN a ZSRR, w stosunku do którego została zastosowana dokładnie procedura proponowana przez Polskę i odrzucona ze względu na rzekomy brak kompetencji (traktat został parafowany 12 września 1990 r.)”61.

Polska ofensywa dyplomatyczna mająca doprowadzić do dopuszczenia Warszawy do stołu rozmów konferencji 2+4, wspomagana przedstawieniem własnego projektu traktatu regulującego charakter granicy, zakończyła się częściowym sukcesem. W czasie pierwszego spotkania ministrów spraw zagranicznych dwóch państw niemieckich i czterech mocarstw 5 maja 1990 roku podjęto decyzję, że polski minister spraw zagranicznych zostanie zaproszony do wzięcia udziału w trzecim spotkaniu konferencji w Paryżu, w czasie którego będą rozważane sprawy dotyczące granic. W oficjalnym oświadczeniu podano, że „Polski minister spraw zagranicznych będzie miał przy tym możliwość zabrania głosu we wszystkich sprawach związanych z kwestią granicy"62. Zastosowana formuła miała charakter rozszerzający i oznaczała, że polski minister będzie mógł poruszyć też inne kwestie niż jedynie formalny przebieg granicy. Za takim rozwiązaniem wypowiedział się minister Szewardnadze $^{63} . Z$ drugiej strony pewnym ograniczeniem było to, że zagadnie-

${ }^{61}$ J. Barcz: op. cit., s. 47.

${ }^{62}$ Oświadczenie końcowe uczestników konferencji "2+4" w Bonn złożone przez Federalnego Ministra Spraw Zagranicznych RFN Hansa-Dietricha Genschera, Bonn 5 maja 1990 r., w: J. Barcz: op. cit., s. 130 i n.

${ }^{63}$ J. Barcz: op. cit., s. 42 . Na ten fakt zwracał także uwagę w rozmowie z K. Skubiszewskim Aleksandr Bondarenko, Dyrektor Departamentu Europejskiego MSZ ZSRR, Notatka Informacyjna dot. rozmów 7 maja br. z A. Bondarenka - specjalnym wystannikiem min. Szewardnadze, członkiem Kolegium MSZ ZSRR, w/s I rundy rozmów "2+4" w Bonn (5 maja br.), 10 maja 1990, w: Polska wobec zjednoczenia..., s. 258 i n. 
nia te miały być przedstawione w czasie sesji, zajmującej się granicami. Warszawa była zainteresowana także sprawami związanymi z miejscem Niemiec $w$ strukturach międzynarodowych, $\mathrm{w}$ tym $\mathrm{w}$ sojuszach militarnych - ale to miało pozostać domeną mocarstw i samych Niemiec. Niemniej jej wizja ładu europejskiego i stosunek do roli ZSRR i Armii Czerwonej nie odpowiadały mocarstwom i mogło to mieć wpływ na sposób, $\mathrm{w}$ jaki umożliwiono Polsce udział w konferencji 2+4.

W międzyczasie RFN zaczęła czynić starania, aby kwestie graniczne z Polską zostały rozwiązane nie poprzez podpisanie traktatu granicznego (parafowanego przed zjednoczeniem), a poprzez przyjęcie i notyfikację rezolucji uchwalonej przez oba parlamenty niemieckie. W czasie rozmów trójstronnych RFN odrzuciła zaś te punkty polskiego projektu traktatu granicznego, które mówiły o tym, że granica opisana w projekcie (także morska) jest podstawowym składnikiem uregulowania pokojowego w Europie (odwołanie do wspomnianego w Umowie Poczdamskiej peace settlement) oraz stwierdzające, że wymieniona granica jest nienaruszalna teraz i w przyszłości. Niechętnie ustosunkowywano się także do dostosowania niemieckiego prawa wewnętrznego do traktatu (chodziło głównie o kwestie obywatelstwa).

Warszawa nie odrzucała koncepcji wystosowania rezolucji przez parlementy niemieckie, o czym minister Skubiszewski i polscy dyplomaci poinformowali $\mathrm{w}$ dwustronnych rozmowach ministrów spraw zagranicznych czwórki (np. J. Bakera w czasie jego wizyty w Polsce 6 maja, D. Hurda w czasie swojej wizyty w Londynie 10 maja) i stronę francuską w czasie dwustronnych konsultacji ministerialnych 14 maja oraz następnie w czasie wizyty premiera Mazowieckiego w Paryżu 28-29 maja. Zwracała jednak uwagę na to, że rezolucja byłaby aktem jednostronnym, wyrażającym wolę polityczną, a nie prawnomiędzynarodową umowa o którą chodziło stronie polskiej, co na ogół spotykało się ze zrozumieniem, przynajmniej co do istoty sprawy.

Warszawa konsekwentnie zwracała uwagę, że konieczne jest odwołanie się do formuł mówiących o ostatecznym uregulowaniu lub uregulowaniu pokojowym, gdyż z związku z konsekwentnie od lat prezentowaną Polsce niemiecką interpretacja może powstać wrażenie, że problem granicy jest nadal otwarty. Po uchwaleniu przez parlamenty 
21 czerwca 1990 roku jednobrzmiących rezolucji, które następnie zostały przyjęte jako własne stanowiska przez rządy, minister Skubiszewski wystosował do ministrów spraw zagranicznych państw uczestniczących w konferencji 2+4 jednobrzmiące w części merytorycznej noty, w których przedstawił powyższe stanowisko. Zaznaczył też, że zdaniem Warszawy wejście w życie traktatu polsko-niemieckiego „winno być skoordynowane $\mathrm{w}$ czasie $\mathrm{z}$ wejściem $\mathrm{w}$ życie prawnomiędzynarodowego »uregulowania końcowego«i nie powinno być od niego późniejsze. Związek w czasie między obu tymi aktami ma istotne znaczenie szczególnie w kontekście dążenia do położenia kresu wszelkim dwuznacznościom prawnym w sprawie statusu granicy polsko-niemieckiej. Co najważniejsze, związek taki wynika $\mathrm{z}$ dotychczasowego stanowiska prawnego Republiki Federalnej Niemiec, które wiązało ze sobą zjednoczenie Niemiec, prawa i odpowiedzialność czterech mocarstw za Berlin i Niemcy jako całość oraz ostateczną decyzję co do prawnego charakteru granicy polsko-niemieckiej" ${ }^{\prime 64}$. Minister podawał przykład orzeczenia Trybunału Konstytucyjnego RFN z 7 lipca 1975 roku. Przedstawienie przez Polskę tej opinii wywołało falę krytyki, szczególnie w RFN. Warszawa była oskarżana o utrudnianie zjednoczenia Niemiec oraz chęć przedłużenia obowiązywania uprawnień czterech mocarstw.

\section{Polska na forum konferencji $2+4$}

W dniu 4 lipca w Berlinie na szczeblu dyrektorów politycznych MSZ odbyło się spotkanie przygotowawcze do posiedzenia paryskiego konferencji 2+4 z udziałem Polski. Celem spotkania było omówienie projektu „Zasad uregulowania w sprawie granic” wypracowanych przez sześciu uczestników konferencji oraz omówienie zagadnień proceduralnych związanych z udziałem ministra Skubiszewskiego.

Warszawa zaproponowała przede wszystkim uzupełnienie projektu „Zasad...” w punkcie pierwszym sformułowaniem, że „granice te [Niemiec po zjednoczeniu - W.J.] są podstawowym składnikiem pokojowego uregulowania (peace settlement) w Europie", a w punkcie drugim

${ }^{64}$ Nota Rzadu Rzeczpospolitej Polskiej skierowana do Rzadu Niemieckiej Republiki Demokratycznej oraz list do J. Bakera z 3 lipca 1990, w: J. Barcz: op. cit., s. 144-151. 
zapowiadającym potwierdzenie granicy przez zjednoczone Niemcy i Polskę w traktacie międzynarodowym dodanie „który wejdzie w życie najpóźniej w dniu wejścia w życie »uregulowania końcowego « ${ }^{65}$.

Warszawa chciała też, aby punkt czwarty, w którym obydwa państwa niemieckie zobowiązywały się, że konstytucja zjednoczonych Niemiec nie będzie zawierała postanowień sprzecznych $\mathrm{z}$ wymienionymi wcześniej zasadami (chodziło o preambułę, art. 23 i 146 Ustawy zasadniczej RFN), był uzupełniony stwierdzeniem „i inne przepisy prawne zjednoczonych Niemiec" ${ }^{\prime 66}$. Postulaty te wywołały dyskusję.

Wskazywano na przykład, że niższe akty prawne nie mogą być sprzeczne z konstytucja, wspomnienie o peace settlement nie jest konieczne, bo konferencja ma przygotować uregulowania końcowe - jedynie delegacja NRD nie odrzucała takich sformułowań. Delegacja francuska i NRD miały zaś mówić o tym, że wejście w życie układu granicznego lepiej powiązać z wygaśnięciem praw mocarstw. Zasugerowano też, aby najpierw rozważyć podpisanie polsko-niemieckiego traktatu granicznego, a później regulującego inne sprawy, co Jerzy Sułek uważał za warte rozpatrzenia $^{67}$. Takie rozwiązanie następnie przyjęto.

Spotkanie ministrów spraw zagranicznych, które miało miejsce w Paryżu 17 lipca 1990 roku, uwzględniło część postulatów polskich, z części Warszawa zrezygnowała ${ }^{68}$. W depeszy do premiera minister poinformował o nieudanej na skutek oporu ministra Genschera próbie dodania do protokołu, że także ustawodawstwo wewnętrzne w Niemczech zostanie dostosowane do zasad „uregulowania końcowego”. Mówił też o konieczności uwzględnienia interesów gospodarczych Polski. W odpowiedzi minister Genscher zaprosił delegację Polską do RFN, na przełomie lipca i sierpnia, aby podjąć rozmowy na temat sukcesji umów gospodarczych. Informował również, że nieprawdziwe były doniesienia prasy francuskiej, iż w związku z udzieleniem przez RFN po-

${ }^{65}$ AMSZ, Dep. IV, 15/94, w. 1, „Zasady uregulowania w sprawie granic” (tłumaczenie) wraz z polskimi propozycjami uzupełnień jako załącznik do Notatki informacyjnej nt. udziału RP w rozmowach „2+4” na szczeblu roboczym, J. Sułek, 10 lipca 1990.

${ }^{66}$ Ibidem.

${ }^{67}$ Ibidem (Notatka informacyjna...).

${ }^{68}$ AMSZ, Dep. IV, z. 15/94, w. 1, Szyfrogram z Paryża, K. Skubiszewski do T. Mazowieckiego, 18 lipca 1990. 
mocy gospodarczej, Polska zrezygnowała ze swoich postulatów względem granicy.

W punkcie pierwszym "Zasad uregulowania sprawy granic" zawarto także zapis: „Potwierdzenie ostatecznego charakteru granic jest istotną częścią składową porządku pokojowego w Europie" - zamiast proponowanego przez Warszawę użycia zawartego w Umowie Poczdamskiej peace settlement $t^{69}$. Do protokołu ze spotkania minister spraw zagranicznych RFN dodał, że traktat o granicy zostanie podpisany w możliwie krótkim czasie po zjednoczeniu, a cztery mocarstwa sojusznicze oświadczyły, że granice zjednoczonych Niemiec będą miały charakter ostateczny. Minister Skubiszewski dodał zaś, że w opinii rządu polskiego oświadczenie to nie stanowi gwarancji granic przez cztery mocarstwa ${ }^{70}$. Warszawa nie chciała, aby granica miała jakieś dodatkowe gwarancje prócz uregulowań prawnych.

Z perspektywy czasu, być może fakt, że do wynegocjowania i podpisania traktatu o granicy doszło po zjednoczeniu Niemiec, w gruncie rzeczy okazał się pozytywny, gdyż nie stworzono podstaw do jego ewentualnego podważania i zakwestionowania przez Trybunał Konstytucyjny. Próbę taką podjęło $\mathrm{BdV}^{71}$.

Podpisanie Traktatu między Rzeczpospolitą Polską a Republiką Federalną Niemiec o potwierdzeniu istniejącej między nimi granicy nastąpiło w Warszawie 14 listopada 1990 roku, a Traktatu między Rzeczpospolitą Polską a Republiką Federalną Niemiec o dobrym sąsiedztwie i przyjaznej współpracy 17 czerwca 1991 roku w Bonn.

\section{Podsumowanie}

Okres jednoczenia obydwu państw niemieckich okazał się trudny dla relacji dwustronnych i rzutujący na późniejsze stosunki pol-

${ }^{69}$ Zasady uregulowania sprawy granic przyjęte podczas spotkania paryskiego w: J. Barcz: op. cit., s. 165; Zapis z przebiegu dyskusji ministrów spraw zagranicznych "2+4" z udziałem min. K. Skubiszewskiego 17 lipca 1990 w Paryżu godz. 15.30-18, w: Polska wobec zjednoczenia..., s. 400-408.

${ }^{70}$ Protokół ze spotkania został przesłany przez stronę francuską stronie polskiej. Oryginał i tłumaczenie w: J. Barcz: op. cit., s. 166-167.

${ }^{71}$ Taki pogląd wyraził A. Hajnicz: op. cit., s. 82. 
sko-niemieckie. Zdaniem Artura Hajnicza, Polska i Niemcy znalazły się „"W sidłach zbędnego konfliktu"72. Władze w Warszawie, reprezentowane przez rząd kierowany przez niekomunistycznego premiera, liczyły na możliwość uzyskania jednoznacznej deklaracji co do uznawania przez RFN granicy za ostateczną, co stawało się naglące w obliczu zmian zachodzących w Polsce i w Europie.

Początkowo wątpliwości chciano wyjaśnić w drodze dwustronnej. Dla Warszawy niezrozumiałe było, że strona niemiecka, jak to było postrzegane w Warszawie, broniła się przed złożeniem jednoznacznej deklaracji. Gdy w związku z upadkiem muru berlińskiego, wydarzeniami w samym NRD oraz po przedstawieniu przez kanclerza Kohla jego planu zjednoczenia Niemiec wizja zjednoczenia stawała się coraz bliższa, Warszawa zaczęła zwracać uwagę na konieczność umiędzynarodowienia problemu zjednoczenia, np. wykorzystania struktur KBWE. Szukała też wsparcia międzynarodowego dla jednoznacznego rozwiązania problemu granicy. Cztery mocarstwa także nie chciały, aby proces jednoczenia Niemiec dokonywał się bez ich udziału, co nie oznaczało, że pragnęły, aby wpływ na niego uzyskało zbyt wiele podmiotów. Po konferencji w Ottawie, w czasie której ustalono, że proces zjednoczenia będzie się odbywał $\mathrm{w}$ ramach konferencji dwóch państw niemieckich i czterech mocarstw okupacyjnych, Warszawa podjęła starania mające umożliwić jej udział w tej części obrad, w czasie której będą podejmowane decyzje jej dotyczące, tzn. odnoszące się do problemu granicznego. Chciała także mieć możliwość wypowiadania się na tematy związane $\mathrm{z}$ bezpieczeństwem, ale to okazało się niemożliwe, przynajmniej w sposób formalny. Trudno przy obecnym poziomie dostępu do źródeł jednoznacznie powiedzieć, czy wynikało to jedynie z przyjętej formuły zjednoczenia, czy też było także pochodną wypowiedzi polityków i dyplomatów polskich, którzy nie wykluczali albo nawet wskazywali na zasadność pozostawienia przez jakiś czas Armii Czerwonej na terenie RFN. Warszawa była przy tym konsekwentnie przeciwna neutralizacji Niemiec. Państwa zachodnie chciały widzieć zjednoczone Niemcy w NATO, z wynikającymi z tego faktu konsekwencjami.

\footnotetext{
${ }^{72}$ Ibidem, s. 77.
} 
Aby uniknąć wszelkich dwuznaczności związanych ze statusem granicy na Odrze i Nysie Łużyckiej, odwołując się do postanowień konferencji w Poczdamie oraz pamiętając o stanowisku prawnym RFN, zgodnie z którym wszelkie decyzje graniczne będą mogły być podjęte przez rząd zjednoczonych Niemiec oraz uregulowane $w$ traktacie pokojowym, Warszawa pragnęła, aby doszło do podpisania z Niemcami traktatu pokojowego albo odpowiadającego mu rangą uregulowania prawnego i uznanego za odpowiadający zapisanej w Układzie Poczdamskim regulacji pokojowej - peace settlement. Zgłosiła też propozycję, aby jeszcze przed zjednoczeniem Niemiec obydwa państwa niemieckie i Polska wynegocjowały i parafowały układ o granicy. Wielka Brytania, Francja, ZSRR oraz NRD właściwie nie widziały przeszkód w takim rozwiązaniu, Stany Zjednoczone miały nieco więcej wątpliwości, ale go nie wykluczały. Takiemu rozwiązaniu konsekwentnie sprzeciwiała się Republika Federalna i prowadziła szeroką akcję dyplomatyczna, lansując nie bez sukcesów swoją wizję uregulowań. Jak wspominałam, posługiwano się przy tym rozwiązaniami przyjętymi podczas konferencji $2+4$, które nie odpowiadały w pełni polskim oczekiwaniom, ale poprzez fakt zobowiązania zjednoczonych Niemiec do podpisania układu o granicy z Polską przynosiły zamknięcie zagadnienia budzącego najwięcej obaw.

Państwa zachodnie były gotowe uwzględnić postulaty RFN, także jej argumentację i wskazywanie na to, że od wojny upłynęło wiele lat, kraj jest stabilną demokracja, lojalnym partnerem w NATO i strukturach europejskich i nie chce, aby mu przypominano bez końca o II wojnie światowej. Na ogół nie wierzono też, aby Kohl odmówił uznania granicy. Zmiany granicy polsko-niemieckiej, przynajmniej w świetle znanych wypowiedzi i źródeł, nie były brane pod uwagę; szukano też sposobu, aby zakończyć stan prawnych niejasności. Niektóre z rozwiązań branych pod uwage przez mocarstwa, tzn. ich gwarancje dla granicy, były odrzucane przez Warszawę, która nie chciała, aby granicy nadano w jakimś sensie status szczególny.

Nawet jeśli niechęć H. Kohla do złożenia publicznej i jasnej deklaracji w sprawie kształtu granicy dziwiła bądź drażniła zachodnich decydentów, polskim dyplomatom i politykom starano się tłumaczyć postę- 
powanie kanclerza Kohla; wskazywano na to, że wynika ono w dużym stopniu z uwarunkowań wewnętrznych, walki wyborczej. Ten argument był zaś dla Warszawy nieakceptowalny, co nie oznacza, że nie zdawano sobie sprawy, iż tak się do pewnego stopnia dzieje, ale nie wykluczano też, że pewnych kwestii strona niemiecka nie chce zamknąć definitywnie i jednoznacznie, aby zachować pole manewru, także w sprawach pochodnych, np. w kwestii obywatelstwa. Dieter Bingen zwraca uwagę, że w niemieckim myśleniu obecna była teoria zastawu (Pfandteorie), zjednoczenie $\mathrm{w}$ zamian za rezygnację $\mathrm{z}$ terenów wschodnich, ale tendencja do traktowania granicy jako karty przetargowej nie ograniczała się wyłącznie do tego kontekstu. Problem był szeroko wykorzystywany w polityce wewnętrznej, zarówno do utrzymania i zdobycia poparcia politycznego, jak i do utrzymania zwartości CDU/CSU. Autor pisał m.in.: "Ze wszystkich kierunków polityki zagranicznej Republiki Federalnej stosunki z Polską najlepiej nadawały się do instrumentalizacji i osiągania celów w polityce wewnętrznej"73. Wskazywał też na powody - historyczne obciążenia i stereotypy, skrywane poczucie winy, brak „podziwu dla polskiej historii i kultury, żadnej akceptacji dla Polski jako państwa równorzędnego mocarstwom zachodnim [...]"74. Włodzimierz Borodziej pisze także o względach emocjonalnych po obu stronach: „Najwyraźniej widać tę warstwę emocjonalną w wypadku Kohla, który od wiosny 1990 r. zżymał się na brak zaufania sąsiadów, podczas kiedy w Warszawie nie rozumiano, jak kanclerz mógł wpaść na pomysł, żeby Polacy zawierzyli obcemu politykowi bezpieczeństwo swojej granicy zachodniej"75. Czasem trudno oprzeć się wrażeniu, że strona niemiecka reprezentowała w swoisty sposób protekcjonalne lub może paternalistyczne podejście. Nie umiano zauważyć faktu, że Polska odzyskiwała niepodległość, rozluźniała więzy z długoletnim Wielkim Bratem, chciała o sobie decydować, być traktowana jako partner w stosunkach międzynarodowych, mający prawo do artykułowania i bronienia swoich interesów, nawet jeśli nie partner równy mocarstwom, to na pewno nie jako podmiot polityki innych. Ten motyw często pojawiał się, choć

\footnotetext{
${ }^{73}$ D. Bingen: op. cit., s. 303.

${ }^{74}$ Ibidem, s. 304.

${ }^{75}$ W. Borodziej: Wstęp, w: Polska wobec zjednoczenia..., s. 35.
} 
nie wprost wyrażany, w rozmowach polskich polityków z ich zachodnimi kolegami (np. w liście po konferencji w Ottawie i w czasie rozmowy z G. Bushem, T. Mazowiecki mówił o Jałcie. Teheran i Jałta pojawiały się też $\mathrm{w}$ wypowiedziach mających głównie adresata wewnętrznego oraz $\mathrm{w}$ prasie.)

Warto też zwrócić uwagę, że kanclerz oczekiwał zrozumienia dla swojej argumentacji o uwarunkowaniach wewnętrznych, mówił o utrudnianiu mu przez Polskę realizowania celów wewnętrznych, tzn. uzyskiwania większego poparcia społecznego dla jego polityki. Politycy i media w RFN oskarżali rząd Mazowieckiego czy, szerzej, Polskę o brak zrozumienia dla jego skomplikowanej sytuacji. Zupełnie nie brano zaś pod uwagę czynnika wewnętrznego jako elementu tworzenia polskiej polityki zagranicznej. Postępowanie Kohla nie ułatwiało sytuacji premierowi Mazowieckiemu jako szefowi rządu wdrażającego trudne reformy gospodarcze, wywołujące coraz wyraźniejsze niezadowolenie społeczne wiosną 1990 roku; dodało jeszcze jeden element, którym należało się zająć - swoiste zagrożenie zewnętrzne poprzez instrumentalizację kwestii granicy. Trudno było oczekiwać od rządu polskiego, że $\mathrm{w}$ takim momencie nie będzie się starał, aby interesy jego kraju zostały w pełni zabezpieczone i aby w swoich kalkulacjach politycznych kierował się celami polityki wewnętrznej kanclerza Kohla. Tradycyjnie kwestia niemiecka pozostawała w Polsce ważnym elementem legitymizacji władz.

Wydaje się też, że kanclerz chciał, aby to wrażenie pozostało takie, że w momencie zjednoczenia to nie on zrezygnował z terenów wschodnich, ale zmusiły go do tego mocarstwa (vide rozmowa $\mathrm{z}$ premierem Mazowieckim, listopad 1989, rozmowa Mazowieckigo z Bushem, marzec 1990 rok). Znamienne jest to, że problemowi rozgrywania kwestii granicy od jesieni 1989 roku oraz stosunkom z Polską w swoich wspomnieniach kanclerz nie poświęcał zbyt wiele uwagi, zapewne zdając sobie sprawę z tego, że jego przekaz jako niemieckiego i europejskiego męża stanu dotrze do licznych czytelników. Sposób, w jaki przedstawił wydarzenia z okresu zjednoczeniowego, zarówno on, jak i jego doradca Telschik, nie pozwala czytelnikowi niemającemu dostępu do polskich publikacji - dodajmy rzadko tłumaczonych na języki konferencyjne 
- zrozumieć zachowania Warszawy, a szczególnie powiązać je z zachowaniem niemieckich aktorów, tzn. spojrzeć na nie w dużym stopniu jako na reakcję na postępowanie kanclerza. Pozbawione kontekstu kulturowego, historycznego, prawnego, politycznego - polskie zachowanie może się więc wydawać, i wydaje się, albo irracjonalne, albo niezwykle interesowne (żądanie reparacji, które przecież „już wypłacono" lub „z których Polska zrezygnowała”, a nie mówienie o odszkodowaniach indywidualnych), albo po prostu antyzjednoczeniowe - utrzymanie uprawnień mocarstw. Więcej niuansów dostarczają zaś wspomnienia ministra Genschera.

W pewnym sensie paradoksalne wydaje się to, że NRD, odchodzące od swojej niedemokratycznej historii, było bardziej skłonne uwzględniać polskie interesy niż RFN, państwo demokratyczne. Szczególnie, gdy pamięta się o lansowanym przez propagandę w PRL podziale na "dobrych" i „złych” Niemców. W wymiarze międzynarodowym, przynajmniej w świetle dostępnych źródeł, Polska mogła liczyć na wsparcie ZSRR - niewykluczone, że było to także związane z jego polityką utrzymywania relacji z byłymi satelitami i wpływów w dezintegrujacym się bloku wschodnim. Dużego wsparcia Warszawie udzielała także Francja i do pewnego stopnia Wielka Brytania.

Zachowania polityczne nie pojawiają się w próżni. Zarówno rząd Polski, jak i spora część społeczeństwa, jak wskazywały na to badania socjologiczne, nie występował(a) przeciwko zjednoczeniu Niemiec. Reakcje polskie zostały zaś w dużym stopniu sprowokowane przez RFN. Po procesie zjednoczenia Niemiec pozostało zaś po stronie polskiej wrażenie, że w jego trakcie Warszawa stoczyła, zakończony pomyślnie, bój o granicę.

\section{Abstract \\ Poland and the German re-unification process in 1989-1990 in the shadow of the border issue}

The period during which both German states underwent unification was a difficult one for relations between Poland and Germany. The authorities in Warsaw, represented by a government with a non-communist prime minister at 
its head, expected to be able to obtain an unambiguous declaration regarding the acknowledgement of the border by the RFG as fixed and irrevocable, which, in view of the changes under way in Poland and in Europe, was becoming an urgent.

Initially, attempts were made, with a view to clarifying the doubts, on a bilateral basis. To Warsaw, it was incomprehensible that the German side would be reluctant to make an unambiguous declaration, perceived as such in Warsaw. Then, with the collapse of the Berlin Wall, the events in the GDR and Chancellor H. Kohl's unveiling of his plan for German unification, the vision of unification drawing ever closer, Warsaw thus become aware of the necessity to internationalise the issue of unification, e.g., by using the CSCE structures, and was also seeking international support for the unambiguous solution of the border issue. In order to avoid any ambiguities related to the status of the border on the Odra and Nysa Łużycka Rivers, and referring to the decisions taken by the Potsdam Conference, as well as having in mind the legal position of the FRG, according to which, any decisions regarding the borders may be made by the government of united Germany and settled in a peace treaty, Warsaw wanted a peace treaty or a legal settlement of equal rank, acknowledged to be equivalent to the peace settlement set forth in the Potsdam Treaty, to be signed with Germany. Not all Warsaw's demands were taken into account. United Germany was, however, placed under an obligation to sign a border treaty with Poland. After the process of German unification was completed, the Polish side was left with the impression that Warsaw had fought the battle for the border successfully. 